\title{
The effects of seasonality and group size on fecal egg counts in wild Przewalski's horses (Equus ferus przewalskii, Poljakov, 1881) in the Chernobyl Exclusion Zone, Ukraine during $2014-2018$
}

\author{
K. SLIVINSKA ${ }^{1, *}$, D. KLICH², N. YASYNETSKA ${ }^{3}$, M. ŻYGOWSKA ${ }^{4}$
}

\begin{abstract}
${ }^{1 *}$ I. I. Schmalhausen Institute of Zoology, NAS of Ukraine, vul. B. Khmelnitskogo 15, Kyiv, 01601, Ukraine, ORCID ID:0000-0002-48498958, E-mail: horsecez@gmail.com; 2Warsaw University of Life Sciences - SGGW, Institute of Animal Sciences, Department of Animal Genetics and Conservation, ul. Ciszewskiego 8, 02-786 Warsaw, Poland, E-mail: daniel_klich@sggw.pl; ${ }^{3 B i o s p h e r e ~}$ Reserve "Askania Nova", Askania-Nova, vul. Parkova 15, Askania-Nova, Chaplinskii r-n, Khersonska oblast, 75230 Ukraine, E-mail: nyasynetska@gmail.com; "Warsaw University of Life Sciences - SGGW, Institute of Veterinary Medicine, Department of Food Hygiene and Public Health Protection, ul. Nowoursynowska 159, 02-776 Warszawa, Poland, E-mail: martazygowska@gmail.com
\end{abstract}

Article info

Received October 22, 2019

Accepted May 25, 2020

\section{Summary}

The aim of this study was to investigate the difference in Fecal Egg Counts (FEC) with regard to group size, age, sex and body condition of wild free-roaming Przewalski's horses in the Chernobyl Exclusion Zone (Ukraine), across different seasons, over a five-year period (2014 - 2018). We hypothesized that horses from larger group sizes would have higher faecal egg counts (FECs). The relationship between FECs and the year and season of sample collection, and age, sex and group size of the horses was analyzed. Generalized linear model using positive strongylid FEC's as a variable response, was used to investigate the differences in FECs between the groups.

Nematode (Strondylidae, Parascaris spp., Habronematidae) and cestode (Anoplocephalidae) eggs were also identified. Stronglyids were the most prevalent helminth egg, and had the highest FECs.

The model for egg counts of strongylids showed that season and group size of horses were statistically significant. Presence of strongylid eggs was not dependent on age and sex of horses. We suggest that this could be a result of parasite transmission between individuals and groups in places were animals aggregate around water sources or collective farms.

Results obtained in this current study broaden the knowledge of gastrointestinal parasites in free-roaming horses under wild natural conditions.

Keywords: gastrointestinal parasite; fecal egg counts; strongylids; Przewalski's horse; Equus ferus przewalskii; Chernobyl Exclusion Zone

\section{Introduction}

Przewalski's horses (Equus ferus przewalskii, Poljakov, 1881) are a rare and endangered subspecies of wild horse (Equus ferus), which are native to the steppes of Central Asia. Until the late 18th century, the natural range of Przewalski's horses was from the Russian Steppes east to Kazakhstan, Mongolia and northern China. Przewalski's horses are threatened by small population sizes, their restricted range, potential hybridization with domestic horses, loss of genetic diversity and disease. In 1969 they were officially declared extinct (Bouman \& Bouman, 1994), but successful reintroductions have qualified this species for reassessment. The number of living captive and reintroduced animals in the International Studbook was estimated at 2444 (1087 males, 1343 females, and 14 unknown sex) on 01.01.2018 (Jaroslav Simek personal comm.). Currently Equus ferus przewalskii qualifies as Endangered (King et al., 2015).

In 1992 the first two reintroduction projects were launched in Mongolia, to restore a population of Przewalski's horse within their native area. At present, 12 large breeding and reintroduction centers

\footnotetext{
$\overline{\text { * }- \text { corresponding author }}$
} 
for Przewalski's horses have been established in Europe (France, Hungary, Ukraine) and in Asia (China, Mongolia, Uzbekistan, Kazakhstan, Russia) (Zimmermann, 2004; Bakirova \& Zharkikh, 2016). In 1998 - 1999 the first captive bred wild horses ( $n=21)$ were introduced to the Chernobyl Exclusion Zone (CEZ) from the Askania Nova Biosphere Reserve in Ukraine. The purpose of this introduction was breeding of this unique equid species as well as to re-wild the area through grazing by wild horses.

Currently there are about 130 Przewalski's horses roaming freely on the grasslands of CEZ (Slivinska et al., 2007; 2017). Groups comprise of either harem or bachelor groups. The number of horses per group ranges from 2 to 20 individuals. Before the transportation to CEZ, Przewalski's horses were dewormed with Albendazole (Zvegintsova et al., 2008). Gastrointestinal parasite monitoring has been conducted from the date of introduction of horses into the CEZ (Slivinska, 2004; Slivinska et al., 2006; Zvegintsova et al., 2008). There were 19 domestic horses which are bred by local services in the same area and the same time and may pose the potential epidemiological hazard for endangered species (Slivinska et al., 2006).

However, over the last decade, no data regarding gastrointestinal parasites within the population of wild Przewalski's horse in the Chernobyl zone has been reported.

Parasitological studies of wild Przewalski's horses kept in zoos, semi-reserves and natural reserves have been previously reported (Dvojnos, 1975; Dvojnos \& Kharchenko, 1994; Epe et al., 2001; Elias et al., 2002; Slivinska et al., 2006; Zvegintsova et al., 2008; Painer et al., 2011; Liu et al., 2016; Kuzmina et al., 2009, 2017). Most of these studies were performed with coprological methods which determined the presence or absence of certain groups of intestinal parasites and estimated the intensity of infection by Fecal Egg Counts (FECs). A few publications have reported information on species composition and structure of intestinal parasites population (Dvojnos \& Kharchenko, 1994; Slivinska \& Dvojnos, 2006; Kuzmina et al., 2009, 2017). Nematodes from the family Strongylidae are the most prevalent and pathogenic group of intestinal parasites of wild and domestic horses worldwide (Dvojnos \& Kharchenko, 1994; Love et al., 1999; Lichtenfels et al., 2008). Coprological examination of intestinal helminths of wild horses is the only ante-mortem method available to study parasites of free-roaming Przewalski's horses in the CEZ (Zvegintsova et al., 2008) as well as wild horses worldwide (Rubenstein \& Hohmann, 1989; Debaffe et al., 2016; Cain et al., 2018; Harvey et al., 2019).

Previously, differences in strongyle faecal egg counts between adults wild Przewalski's horses and their social groups (bachelors/ harems) in CEZ were recorded during the first years of the existence of the population (Slivinska, 2004, Zvegintsova et al., 2008). Higher (Slivinska, 2004) or lesser (Zvegintsova et al., 2008) strongyle faecal egg counts were found in bachelor groups compared to harem groups of wild Przewalski's horses in CEZ. Zvegintsova et al. (2008) speculated that the differences in FEC between some adult wild Przewalski's horses in CEZ might be affected by their different immune responses to helminthiases. However, yet no systematic study has been performed the parasite loads with regard to social and environmental factors in CEZ. This is important because the population of the Przewalski's horse in CEZ may be a reservoir for free populations of this species. The species has still endangered status (King et al., 2015), and the population is exposed to many threats, including environmental ones (e.g. Kaczensky et al., 2011). Moreover, it is important to assess the threat from parasites for Przewalski's horses in the forest-meadow landscape.

The aim of this study was to investigate the difference in Fecal Egg Counts (FECs) with regard to group size, age, sex and body condition of wild free-roaming Przewalski's horses in the Chernobyl Exclusion Zone (Ukraine), across different seasons, over a five-year period $(2014$ - 2018). We hypothesized that horses from larger group sizes would have higher FEC's.

\section{Materials and Methods}

\section{Study Area}

The CEZ is located c. $200 \mathrm{~km} \mathrm{~N}$ of Kiev, Ukraine $\left(51.3^{\circ} \mathrm{N}\right.$; $\left.30.005^{\circ} \mathrm{E}\right), 123 \mathrm{~m}$ above sea level. This zone covers an area of $2,600 \mathrm{~km}^{2}$ and falls entirely within the Polesie Lowland, Russian Plain. The climate in the CEZ is humid, with relatively mild winters and warm summers. The mean annual temperature is $5-7^{\circ} \mathrm{C}$, with a mean temperature in July of $18^{\circ} \mathrm{C}\left(\max .32^{\circ} \mathrm{C}\right)$, and in January of $-6^{\circ} \mathrm{C}\left(\min .-25^{\circ} \mathrm{C}\right)$. The annual precipitation ranges from 550 to $750 \mathrm{~mm}$. The snow cover lasts on average c. 50 days per year. The mean depth of the snow cover is $12-13 \mathrm{~cm}$ (Barjachtar et al.(ed), Chernobyl disaster 1996).

The CEZ is surrounded by metal fencing two meters high. Approximately c. 50 peasants also are still living in the CEZ; only few other persons have constant access to this area. Before the nuclear disaster, the CEZ consisted of farmlands with patchy areas of forest. Currently, ca. $60 \%$ of the area is covered with forests, $50 \%$ of which is pine forest and the remaining consists of abandoned arable grounds, meadows, pastures and human settlements.

\section{Data collection}

Faecal samples from wild Przewalski's horses were collected during five field trips between April 2014 and September 2018. Each survey was performed over $7-10$ days, using a car to travel between sampling sites. When horses were sighted, they were observed with the aid of binoculars or a telescope. The number of individuals was recorded in each group. Where possible, the age class and sex of each individual were recorded (Zharkikh 2003). Clinical signs that may be associated with parasitism, such as body condition (slim; fat; regular) and poor coat condition, were noted. The age of each horse was assessed visually and assigned to one of four groups: a) < 1 year, b) $1-3$ years, c) $3-10$ years, and d) $>10$ years. After the basic census data were collected, the individual horses were observed during defecation. 

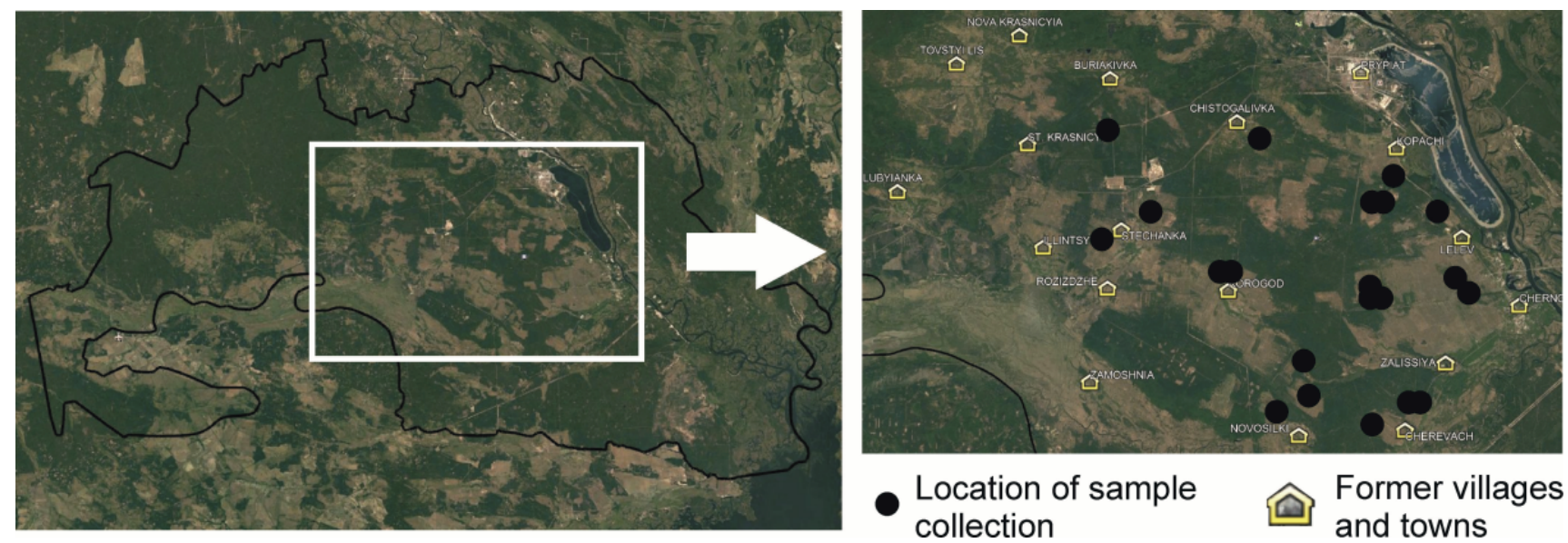

Fig. 1. Location of fecal sample collection in Chernobyl Exclusion Zone.

During this time the location of feces deposition was determined for each horse. After the group moved to graze to other sites of the meadow, samples of feces were collected and the GPS location was recorded for each collection (Fig. 1). During each survey, samples of fresh feces that were found on roads or other open places, were also collected. The samples were cooled in a portable refrigerator, transported to a laboratory and stored in a refrigerator at $3^{\circ} \mathrm{C}$ for $2-6$ days, until analyzed. 72 fecal samples were performed according to the spring season (13 in 2014, 14 in 2015, 15 in 2016 and 30 in 2017, respectively) and 46 fecal samples were performed according to the autumn season (38 in 2015 and 8 in 2018, respectively). In total, 118 fecal samples were examined from April 2014 to September 2018. Although we were able to distinguish horses during collection of samples during one year, we were not able to check weather samples were collected from the same horse during the following years.

\section{Fecal Egg Counts}

Fecal egg counts (FECs) were performed using the McMaster technique, with a sensitivity of 25 Eggs Per Gram feces (EPG) (Herd, 1992). Mean FEC (average number of EPG per infected animal) and prevalence (percentage of animals infected) were calculated for each horse individually, and assigned to either 'harems' or 'bachelor groups'. Fresh feces that were opportunistically found on roads or other open places were assigned as 'unknown groups'. A total of 118 horses from 21 groups (14 harems; 4 bachelor groups; 3 unknown groups) were examined.

\section{Data elaboration and statistics}

For further analysis, we used samples that were positive for strongylids egg counts, which was the most common species observed. We excluded 8 samples where other species of parasites were more common (over 50 eggs EPG) since different parasite species can influence the FECs of other parasitic species (Paterson \& Lello, 2003). To investigate the differences in strongylid parasitic infection, we used a generalized linear model with egg counts of strongylids as a response variable. The sex, age of each known horse, season (spring and autumn) and the year of the sample collection were fixed factors; the group size was a covariate. In this model we used a Tweedie distribution with log link after comparison with the Poisson and a negative binomial distribution model using the Akaike information criterion (AIC) and the Bayesian information criterion (BIC). The model with Tweedie distribution showed lower values of both information criteria (AIC and BIC). Selection of the models was performed with backward elimination procedure basing on the AIC values. The model was constructed with SPSS software (version 24.0, IBM Corporation, Armonk, NY).

\section{Results}

Nematode (Strongylidae, Parascaris spp., Habronematidae) and cestode (Anoplocephalidae) eggs were found in feces of wild Przewalski's horses (Table 1). The prevalence of strongylids in-

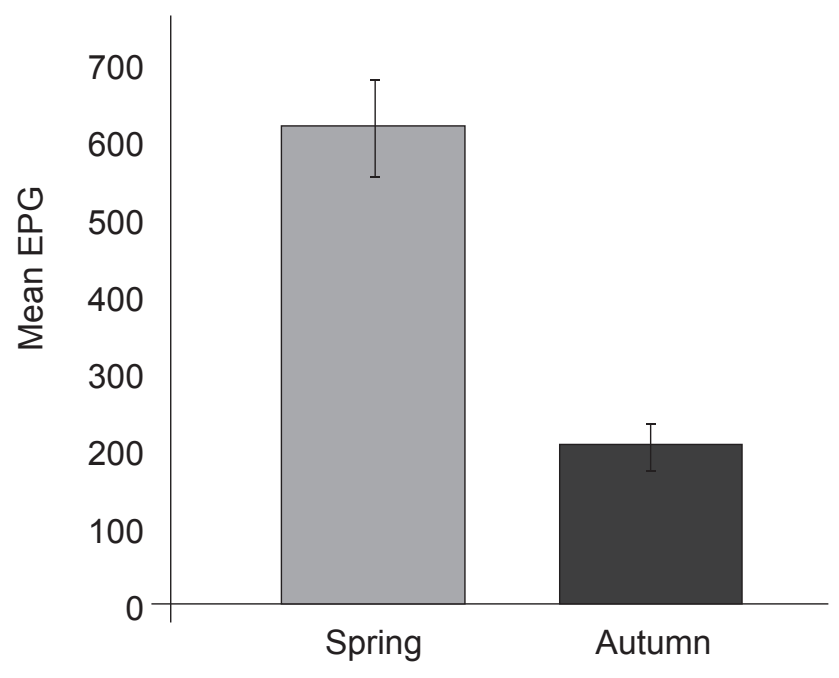

Fig. 2. Mean EPG of strongylids in feces of Przewalski's horses in two analyzed seasons and pairwise comparisons with Bonferroni adjustment ( $\chi 2=45.75, p=0.000, N=71$ for Spring and $N=39$ for Autumn). 
Table 1. Egg counts of the gastrointestinal parasites of wild Przewalski's horses in the Chernobyl Exclusion Zone between April 2014 to September 2018.

(EPG - eggs per gram of feces; El - prevalence of infections; FEC - mean fecal egg counts, SD - standard deviation)

\begin{tabular}{|c|c|c|c|c|c|c|c|c|c|c|c|c|c|c|}
\hline \multirow[t]{2}{*}{ Year } & \multirow{2}{*}{$\begin{array}{l}\text { Group type } \\
\text { ( } n=\text { number of } \\
\text { horses), }\end{array}$} & \multirow{2}{*}{$\begin{array}{l}\text { No. of } \\
\text { feces } \\
\text { samples }\end{array}$} & \multicolumn{3}{|c|}{ Strongylidae } & \multicolumn{3}{|c|}{ Parascaris spp. } & \multicolumn{3}{|c|}{ Habronematidae } & \multicolumn{3}{|c|}{ Anoplocephalidae } \\
\hline & & & El, \% & $\begin{array}{l}\text { FEC, } \\
\text { EPG }\end{array}$ & $\pm S D$ & El, \% & $\begin{array}{l}\text { FEC, } \\
\text { EPG }\end{array}$ & $\pm S D$ & El, \% & $\begin{array}{l}\text { FEC, } \\
\text { EPG }\end{array}$ & $\pm S D$ & El, \% & $\begin{array}{l}\text { FEC, } \\
\text { EPG }\end{array}$ & $\pm \mathrm{SD}$ \\
\hline \multirow[t]{2}{*}{2014} & Harem (5) & 5 & 100 & 470 & 258.2 & & & - & - & - & & 60 & 41.7 & 29.9 \\
\hline & Harem (8) & 8 & 100 & 925 & 512.3 & - & - & - & - & - & - & - & - & - \\
\hline \multirow[t]{7}{*}{2015} & Harem (15) & 3 & 100 & 158.3 & 52 & - & - & & - & - & & - & - & \\
\hline & Harem (4) & 3 & 66.7 & 25 & 14.4 & - & - & & - & - & & - & - & \\
\hline & Harem (5) & 2 & 100 & 37.5 & 17.7 & - & - & & - & - & & - & - & \\
\hline & Harem (7) & 6 & 100 & 125 & 52.4 & - & - & & - & - & & - & - & \\
\hline & Harem (11) & 3 & 66.7 & 187.5 & 175 & - & - & & - & - & & - & - & \\
\hline & Bachelors (8) & 8 & 100 & 33.4 & 166.9 & - & - & & 12.5 & 25 & & 25 & 25 & 11.6 \\
\hline & Unknown & 27 & 88.9 & 117.1 & 142.1 & 11.1 & 191.7 & 76.2 & - & - & & 7.4 & 25 & 6.7 \\
\hline \multirow[t]{4}{*}{2016} & Harem (12) & 7 & 100 & 660.7 & 677.4 & - & - & & - & - & & - & - & \\
\hline & Harem (3) & 3 & 100 & 300 & 201 & - & - & & - & - & & - & - & \\
\hline & Bachelors (5) & 4 & 100 & 487.5 & 512.6 & 25 & 25 & & - & - & & - & - & \\
\hline & Unknown & 1 & 100 & 250 & & - & - & & - & - & & - & - & \\
\hline \multirow[t]{5}{*}{2017} & Harem (8) & 4 & 100 & 718.8 & 451 & - & - & & - & - & & - & - & \\
\hline & Harem (14) & 11 & 100 & 788.6 & 377.9 & - & - & & - & - & & 9.1 & 25 & \\
\hline & Harem (3) & 3 & 100 & 250 & 106.1 & 33.3 & 25 & & - & - & & 66.6 & 25 & \\
\hline & Bachelors (11) & 11 & 100 & 479.5 & 237.4 & 18.2 & 112.5 & 123.7 & - & - & & 9.1 & 25 & \\
\hline & Unknown & 1 & 100 & 600 & & - & - & & - & - & & - & - & \\
\hline \multirow[t]{3}{*}{2018} & Harem (3) & 2 & 100 & 250 & 70.7 & - & - & - & - & - & - & - & - & - \\
\hline & Harem (9) & 2 & 100 & 112.5 & 17.7 & 50 & 25 & - & - & - & - & - & - & - \\
\hline & Bachelors (6) & 4 & 100 & 193.8 & 104.8 & 25 & 25 & - & - & - & - & - & - & - \\
\hline
\end{tabular}

fections was 66.7 to $100 \%$ in observed groups of horses, during the whole period of observation. The mean FEC of strongylids in observed groups of horses fluctuated between $25 \pm 14.4-925 \pm$ 512.3 EPG. In samples collected in spring season over all study period the mean FEC of strongylids averaged 555.2 \pm 414.5 EPG, with the prevalence of $100 \%$. In samples collected in autumn season the mean FEC of strongylids averaged 142.1 \pm 95.1 EPG, with the prevalence of $89.1 \%$.

The prevalence of parascarides infection was also recorded and ranged from 11.1 - $50 \%$. The mean FEC of Parascaris spp. ranged from $25-191.7 \pm 76.2$. Habronematids eggs were only detected in a single horse in 2015 (12.5\%; EPG = 25).

In additional, a few cestode eggs were detected in some groups of horses $(7.4-66.6 \% ; 25-41.7 \pm 29.9$ EPG) (Table 1).

Externally observable clinical signs of parasitosis among these wild horses were not noted in any individual. All horses were in good clinical condition, with 'regular' body condition score and typical coat condition.

The best model for egg counts of strongylids in feces of Przewalski's horses included the season, age and group size; and was highly statistically significant (Table 2). The model selection proce- dure excluded the variable "sex", "year" and all interactions. Horses presented a significantly higher parasitic infection level during spring than autumn $(p=0.000)$. During Spring, feces contained over three times a higher number of strongylids eggs than during autumn (mean= 624.5 and 219.6, respectively) - Fig. 2. Group size was positively correlated to strongylid FECs. The bigger the group size, the higher the strongylid FECs ( $p=0.045)$. Age was not statistically significant in this model.

\section{Discussion}

The dominant helminth group (both in terms of prevalence and FEC) was Strongylidae. Domination by strongylids in the intestinal helminthic fauna of horses of the Chernobyl population has been previously reported (Slivinska, 2004; Slivinska et al., 2006; Zvegintsova et al., 2008). Other potentially important gastrointestinal parasites (Parascaris spp., Habronematids and Cestodes: Anoplocephalidae) in the Przewalski's horses in CEZ were not significant in this study, as also reported by Slivinska (2004) and partially by Zvegintsova et al. (2008). Earlier parasitological investigation (Zvegintsova et al., 2008) has been recorded the mean 
Table 2. Effects season, age and group size on the egg counts of strongylids in feces of Przewalski's horses $(\chi 2=56.06 ; d f=4 ; p=0.000, N=110)$. Non-significant sex and year of sample collection were excluded by AIC backward elimination procedure.

\begin{tabular}{lccc}
\hline Source & Wald $\chi^{2}$ & $d f$ & $P$ \\
\hline Intercept $^{*}$ & 961.1 & 1 & 0.000 \\
Season $^{*}$ & 52.58 & 1 & 0.000 \\
Group size $^{*}$ & 4.03 & 1 & 0.045 \\
Age & 1.65 & 2 & 0.439 \\
\hline
\end{tabular}

FEC in all harem's and bachelor's groups (prevalence $93.1 \%$ ) with a range of 80 to 140 EPG over the first eight years (1998 - 2006) after transportation of Przewalski's horses in the CEZ. In our study, the mean FEC of strongylids in observed groups of horses fluctuated between $25 \pm 14.4-925 \pm 512.3$ EPG (prevalence 66.7 to $100 \%$ ) during the whole period of our observation. In our opinion, the differences may be due to the use of the different methods of the fecal egg counts as well as other seasons of the sample collection.

Strongylids are prevalent in horses of different breeds and throughout different regions of the world, despite huge climatic differences (Ogbourne, 1976; Anderson \& Hasslinger, 1982; Reinemeyer et al., 1984; Krecek et al., 1989; Bucknell et al., 1995; Silva et al., 1999; Gawor, 1995; Lind et al., 2003; Kuzmina et al., 2005).

Wild horses of the CEZ were documented to have variable strongylid FECs, which depended on the season of sample collection and horses' group size (Table 2, Fig. 2). In our survey all wild Przewalski's horses were examined in spring and early autumn when the adult strongylid populations are considered to reach their highest level (Reinemeyer et al., 1986).

Mean total egg emissions differ significantly depends of season according to our research. Four times higher values of strongylid FECs were in spring than in autumn (555.2 \pm 414.5 and 142.1 $\pm 95.1 \mathrm{EPG}$, respectively).Our findings confirm previous studies, where the level of strongylid egg shedding depended on the season (Dobrowolska \& Grabda, 1951; Gawor, 1995). However, intensity of infection usually decreases during winter due to a decrease in strongyle egg production (Trach, 1986; Baudena et al., 2000). In addition, we recorded that strongylid FECs increased during the rainy season and decreased during the dry season (Betlejewska, 2000; Epe et al., 2001).

Group size was positively correlated to strongylid FECs. The results confirm previous studies, where the larger the group the higher the FEC (Rubenstein \& Hohmann, 1989; Harvey et al., 2019). We hypothesize that this could be a result of parasite transmission between individuals within group, which is observed in areas where animals aggregate (Reinemeyer \& Nielsen, 2018). Moreover, transmission may be higher than stated in other studies, because we have found a lack of influence of sex and age on strongylid FECs. In general, sex and age is indicated to influence the infection level in horses (Côté \& Poulin, 1995; Bucknell et al., 1995; Romaniuk et al., 2004; Fikru et al., 2005; Francisco et al., 2009; Kornas et al., 2010). Significant differences in gastrointes- tinal parasite communities associated with sex were observed for intestinal strongylids: mares had significantly higher numbers of strongylids as compared to stallions (Slivinska et al., 2016). Moreover, significant differences with infection of intestinal parasites associated with age were observed for Strongylidae and Parascaris equorum infections in different breeds of horses (Lind et al., 1999; Larsen et al., 2002; Kornas et al., 2010; Kuzmina, 2012, Slivinska et al., 2016), and this supports the concept of the development of anti-parasite immunity in horses with age (Klei \& Chapman, 1999). We suggest that, within the CEZ, wild horses may transmit the parasites within group at watering places or former collective farms. Within the CEZ, there are vast areas where watering places are scarce and some of them are small in size. The necessity of water access can be a reason for horses to aggregate in small areas near the waterholes. We also speculate, that another places which may increase parasite transmission are the former collective farms. Przewalski's horses use the abandoned buildings of former collective farms to protect themselves against environmental challenges (Klich et al., 2017, Schlichting et al., 2019). There is the proximity with former collective farms where animals gather and location of sample collection in our study (Fig. 1). However, there may be also other places of aggregation, that could influence the overall general infection levels of parasites in wild horses within the group regardless the sex and age. Transmission between groups in aggregation places is less probable. Groups may appear in the same areas, at least partially, however, during vegetation season harems of Przewalski's horses tend to keep distance between themselves (Klich et al., 2019). Although, in the forest meadow mosaics such behavior was not described, we expect to behave horses in a similar way.

Results obtained in this study broaden the knowledge of parasite communities in free-roaming wild horses in the Chernobyl Exclusion Zone. This paper also documents factors that could influence the parasitic infections in wild horses under natural conditions.

\section{Conclusions}

Results obtained in this study broaden the knowledge of parasite communities in free-roaming wild Przewalski's horses in the Chernobyl Exclusion Zone. This paper also documents factors that could influence the parasitic infections in wild horses under natural conditions of forest-meadow landscape.

Results presented in this study gives an overview of the situation 
over the years in protected animals inhabiting a peculiar niche, where the material is difficult to access and there are not many sources of knowledge regarding the health and parasitological status of these animals.

Results obtained in this study broaden the knowledge of parasite communities in free-roaming wild horses in the Chernobyl Exclusion Zone. This paper also documents factors that could influence the parasitic infecstations in wild horses underin natural conditions.

\section{Conflicts of interest}

The authors declare no conflicts of interest.

\section{Ethical Approval and/or Informed Consent}

For this study formal consent is not required.

\section{Funding}

This research did not receive any specific grant from funding agencies in the public, commercial, or not-for-profit sectors.

\section{Acknowledgements}

The authors thanks to Alexander Borovskyi, Denis Vishnevskyi, Viktor Kuchynskyi and Vasilii Davydenko for assistance in collecting field data, and Prof. Terry R. Spraker from the Colorado State University, USA and Dr. Andrea M. Harvey from the Centre for Compassionate Conservation, School of Life Sciences, Faculty of Science, University of Technology Sydney, Sydney, NSW, Australia, for invaluable comments and corrections in this manuscript.

\section{References}

Anderson, M.A., Hasslinger, I.G. (1982): Cyathostominae and other strongyles of horses in the federal republic of Germany. J S Afr Vet Assoc, 53 (3): $195-197$

BAKIROVA, R.T., ZHARKIKH, T.L. (2016): The first stage of the project on the re-introduction of the Przewalski horse to the Orenburg Reserves. II. The transportation of the first group of founders of the population. Steppe Bulletin, 46: 45 - 49 (In Russian)

Baudena, M.A., Chapman, M.R., French, D.D., Klei, T.R. (2000) Seasonal development and survival of equine cyathostome larvae on pasture in south Louisiana. Vet Parasitol, 88: 51 - 60. DOI: 10.1016/S0304-4017(99)00198-3

BETLEJEWSKA, K. (2000): Dynamic of the infestation of the small strongylides (Cyathostominae) of the horses during the annual cycle. Med Weter, 56 (1): 36 - 38 (In Polish)

Bouman, I., Bouman, J. (1994): The history of Przewalski's horse. In: Boyd, L., Houpt, K.A. (Eds) Przewalski's horse: The history and biology of an endangered species. Suny, New York: State University of New York Press, pp 5 - 38
Bucknell, D.G., Gasser, R.B., Beveridge, I. (1995): The prevalence and epidemiology of gastrointestinal parasites of horses in Victoria, Australia. Int J Parasitol, 25(6): 711 - 724. DOI: 10.1016/00207519(94)00214-9

Cain, J.L., Jarisch, K., Macaluso, K.R., LuedtKe, B.E. (2018): Correlation between fecal egg count, presence of Strongylus vulgaris, and body score of feral horses on Fort Polk, Louisiana. Vet. Parasitol. Reg. Stud. Rep., 13: 14 - 17. DOI: 10.1016/j.vprsr.2018.03.002 BARJACHTAR, V.G., et al.(Ed) (2001): Chernobyl disaster 1996. Naukova Dumka Pres., Kyiv (In Russian)

Côté, I.M., PoulinB, R. (1995): Parasitism and group size in social animals: a meta-analysis. Behav Ecol, 6(2): 159 - 165. DOI: 10.1093/beheco/6.2.159

Debaffe, L., Mcloughlin, P.D., Medill, S.A., Stewart, K., Andres, D., Shury, T., Wagner, B., Jenkins, E., Gilleard, J.S., Poissant, J. (2016): Negative covariance between parasite load and body condition in a population of feral horses. Parasitology, 143(8): 983 - 997 DOI: 10.1017/S0031182016000408

DobrowolsKA, D., GrabDA, E. (1951): Annual cycle of the nematodes eggs output in horses. Med Weter, 7(4): 235 - 236 (In Polish) Dvojnos, G.M. (1975): Helminthfauna of the Przewalski's horse in the Askania-Nova reserve. Parasites and parasitoses of animal and man. Naukova Dumka, Kyiv, 122 - 126 (In Russian)

Dvojnos, G.M., KhaRChenKo, V.A. (1994): Strongylida of wild and domestic horses. Naukova dumka, Kyiv (In Russian)

Elias, F., Sterregaard, F., Baumgartner, R., Walzer, C., Slotta-Bachmayr, L., Ganbataar, O., Bajalagmaa, N., Isenbügel, E., Deplazes, P. (2002): Parasitologic examinations in reintroduced Przewalski horses (Equus c. przewalskii) compared to mongolian domestic horses (E. caballus) and Dschiggetais (E. h. hemionus) in the Dzungarian Gobi, Mongolia. Pro. EAZWV \& EWDA May $8-12,2002$. Heidelberg, Germany, pp. $233-240$

Epe, C., Kings, M., Stoye, M., Böer, M. (2001): The prevalence and transmission to exotic equids (Equus quagga antiquorum, Equus przewalskii, Equus africanus) of intestinal nematodes in contaminated pasture in two wild animal parks. J Zoo Wildl Med, 32(2): $209-217$

Fikru, R., Reta, D., Teshale, S., Bizunesh, M. (2005): Prevalence of equine gastrointestinal parasites in western high lands of Oromia, Ethiopia. Bull Anim Health Prod Afr, 53(3): 161 - 166. DOI: 10.4314/bahpa.v53i3.32704

Francisco, I., Arias, M., Cortińas, F.J., Francisco, R., Mochales, E., Dacal, V., Suárez, J.L., Uriarte, J., Morrondo, P., Sánchez-AndRADE, R., Diez-Baños, P., Paz-Silva, A. (2009): Intrinsic factors influencing the infection by helminth parasites in horses under an oceanic climate area (NW Spain). J Parasitol Res, 2009(2009). DOI: 10.1155/2009/616173

GaWOR, J.J. (1995): The prevalence and abundance of internal parasites in working horses autopsied in Poland. Vet Parasitol, 58(1 - 2): 99 - 108. DOI: 10.1016/0304-4017(94)00698-C

Harvey, A.M., Meggiolaro, M.N., Hall, E., Watts, E.T., Ramp, D., ŠLAPETA, J. (2019): Wild horse populations in south-east Australia 
have a high prevalence of Strongylus vulgaris and may act as a reservoir of infection for domestic horses. Int J Parasitol Parasites Wildl, 8: 156 - 163. DOI: 10.1016/j.jppaw.2019.01.008

HERD, H.P. (1992): Performing equine fecal egg counts. Vet Med (USA), 87(3): $240-244$

Kaczensky, P., Ganbataar, O., Altansukh, N., Enkhsaikhan, N., Stauffer, C., Walzer, C. (2011): The danger of having all your eggs in one basket - winter crash of the re-introduced Przewalski's horses in the Mongolian Gobi. PLoS ONE, 6(12): e28057. DOI: 10.1371/journal.pone.0028057

King, S.R.B., Boyd, L., Zimmermann, W., Kendall, B.E. (2015): Equus ferus (errata version published in 2016). The IUCN Red List of Threatened Species 2015: e.T41763A97204950. DOI: 10.2305/ IUCN.UK.2015.2.RLTS.T41763A45172856.en

KLel, T.R., Chapman, M.R. (1999): Immunity in equine cyathostome infections. Vet Parasitol, 85(2 - 3):123 - 136. DOI: 10.1016/ S0304-4017(99)00093-X

KLICH, D., SLIVINSKA, K., YASYNETSKA, N. (2017): The use of abandoned buildings by Przewalski's horses in the Chornobyl Exclusion Zone, Ukraine. J Vet Behav, 22: 13 - 16. DOI: 10.1016/j. jveb.2017.09.001

Klich, D., ZharkikH, T.L., Łopucki, R., Bakirova, R.T., Bulgakov, E.A., Petrov, V.Yu. (2019): The space use by Przewalski's horses of the semi-free population during first years after their reintroduction to Orenburg State Nature Reserve, Russia. Nat Conserv Res, 4 (Suppl. 2): 41 - 48. DOI: 10.24189/ncr.2019.031

Kornaś, S., Cabaret, J., Skalska, M., Nowosad, B. (2010): Horse infection with intestinal helminths in relation to age, sex, access to grass and farm system. Vet Parasitol, 174(3 - 4): 285 - 291. DOl: 10.1016/j.vetpar.2010.09.007

KRECEK, R.C., ReinICKE, R.K., HoRAK, I.G. (1989) Internal parasites of horses on mixed grassveld and bushveld in Transvaal, Republic of South Africa. Vet Parasitol, 34(1 - 2): 135 - 143. DOI: 10.1016/0304-4017(89)90173-8

Kuzmina, T.A., Kharchenko, V.A., Starovir, A.I., Dvojnos, G.M. (2005): Analysis of the strongylid nematodes (Nematoda: Strongylidae) community after deworming of brood horses in Ukraine. Vet Parasitol, 131(3 - 4): 283-290 DOI: 10.1016/j.vetpar.2005.05.010 KuzMina, T.A., ZVEGINTSOVA, N.S., ZHARKIKH, T.L. (2009): Strongylid community structure of the Przewalski's horses (Equus ferus przewalskii) from the Biosphere Reserve "Askania-Nova", Ukraine. Vestn Zool, 43(3): e-5 - e-11. DOI: 10.2478/v10058-009-0010-1

KuZMINA, T.A., ZveGINTSOVA, N.S., ZHARKIKH, T.L. (2017): Gastrointestinal Parasite Community in a New Population of the Przewalski's Horse (Equus ferus przewalskii) in the Orenburg State Reserve, Russia. Vestn Zool, 51(3): 243 - 250. DOI: 10.1515/vzoo-20170030

KuzminA, T.A. (2012): Analysis of regional peculiarities of strongylids (Nematoda: Strongylidae) biodiversity in domestic horses in Ukraine. Vestn Zool, 46(1): e-7 - e-15. DOI: 10.2478/v10058012-0002-4

Larsen, M.M., Lendal, S., Chriél, M., Olsen, S.N., Bjørn, H. (2002):
Risk factors for high endoparasitic burden and the efficiency of a single anthelmintic treatment of Danish horses. Acta Vet Scand, 43(2): 99 - 106 DOI: 10.1186/1751-0147-43-99

Lichtenfels, J.R., KHARChENKo, V.A., Dvojnos, G.M. (2008): Illustrated identification keys to strongylid parasites (Strongylidae: Nematoda) of horses, zebras and asses (Equidae). Vet Parasitol, 156(1 - 2): 4 - 161 DOI: 10.1016/j.vetpar.2008.04.026

Lind, E.O., Eysker, M., Nilsson, O., UgGla, A., Höglund, J. (2003): Expulsion of small strongyle nematodes (Cyathostomin spp.) following deworming of horses on a stud farm in Sweden. Vet Parasitol, 115(4): 289 - 299. DOI: 10.1016/S0304-4017(03)00200-0 Lind, E.O., Hoglund, J., LJungström, B.L., Nilsson, O., UgGLA, A. (1999): A field survey on the distribution of strongyle infections of horses in Sweden and factors affecting faecal egg counts. Equine Vet J, 31(1): 68 - 72. DOI: 10.1111/j.2042-3306.1999.tb03793.x LIU, S.H., Hu, D.F., LI, K. (2018): Parasites observed in the proximal alimentary tract of a Przewalski's horse in China. Equine Vet Educ, 30(1): 20 - 23. DOI: 10.1111/eve.12593

Love, S., MurPhy, D., Meloro, D. (1999): Pathogenicity of cyathostome infection. Vet Parasitol, $85(2-3)$ : 113 - 122. DOI: 10.1016/ S0304-4017(99)00092-8

Ogbourne, C.P. (1976): The prevalence, relative abundance and site distribution of nematodes of subfamily Cyathostominae in horses killed in Britain. J Helminthol, 50(3): 203 - 214. DOI: 10.1017/S0022149X00027760

Painer, J., Kaczensky, P., Ganbahtar, O., Huber, K., Walzer, C. (2011): Comparative parasitological examination on sympatric equids in the Great Gobi "B" Strictly Protected Area, Mongolia. Eur J Wildl Res, 57(2): 225 - 232 DOI:10.1007/s10344-010-0415-8 PATERSON, S., LelLo, J. (2003): Mixed models: getting the best use of parasitological data. Trends Parasitol, 19(8): $370-375$. DOI: 10.1016/S1471-4922(03)00149-1

Reinemeyer, C.R., Smith, S.A., Gabel, A.A., Herd, R.P. (1986): Observations on the population dynamics of five cyathostome nematode species of horses in northern USA. Equine Vet J, 18(2): 121 - 124. DOI: 10.1111/j.2042-3306.1986.tb03564.x

Reinemeyer, C.R., Smith, S.A., Gabel, A.A., Herd, R.P. (1984): The prevalence and intensity of internal parasites of horses in the USA. Vet Parasitol, 15(1): 75 - 83. DOI: 10.1016/0304-4017(84)90112-2 Reinemeyer, C.R., Nielsen, M.K. (2018): Handbook of Equine Parasite Control. John Wiley \& Sons, Inc. DOI: 10.1002/9781119382829 RomAnIUK, K., ResZKA, K., LASOTA, E. (2004): Influence of animal breeding manner on the occurrence of internal parasites. Wiad Parazytol, 50(3): 647 - 651

Rubenstein, D.I., Hohmann, M.E. (1989): Parasites and social behavior of island feral horses. Oikos, 55(3): $312-320$

Schlichting, P.E., Dombrovski, V., BeAsLey, J.C. (2020): Use of abandoned structures by Przewalski's wild horses and other wildlife in the Chernobyl Exclusion Zone. Mamm Res, 65, 161 - 165. DOI: 10.1007/s13364-019-00451-4

Silva, A.V.M., Costa, H.M.A., Santos, H.A., Carvalho, R.O. (1999): Cyathostominae (Nematoda) parasites of Equus caballus in some 
Brasilian States. Vet Parasitol, 86(1): 15 - 21. DOI: 10.1016/ S0304-4017(99)00078-3

SLIVINSKA, K.A. (2004): The Przewalski's horse (Equus przewalskii Poljakov, 1881) under conditions of the Chornobyl Exclusion Zone (an ecological and parasitological analysis). Dissertation, Institute of Zoology NASU, Kyiv (In Ukrainian)

Slivinska, K., Dvojnos, G., BorovskiY, A. (2007): The role of the Przewalski horse in the renaturalization of the Chornobyl Exclusion Zone, Ukraine. In: Pearson, R.A., MuIR, C.J., FarRow, M. (Eds) The Future for Working Equines, The Fifth International Colloquium on Working Equines. Proceedings, $296-299$

SlivinsKa, K., DvoJnos, G., KopIJ, G. (2006): Helminth fauna of sympatric Przewalski's (Equus przewalskii Poljakov, 1881) and domestic horses ( $E$. caballus $L$.) in the Chernobyl exclusion zone, Ukraine. Helminthologia, 43: 27 - 32. DOI: 10.2478/s11687-0060006-0

SlivinSKa, K., YasynetSKA, N., KLICH, D. (2017): Przewalski's Wild Horses and Their 18th Years Management in the Chornobyl Exclusion Zone, Ukraine. In Proceeding of the International Symposium
Ecology 2017, Ercyes University, May, 11 - 13, Kayseri, Turkey, pp. $90-98$

SlivinSKA, K., WróbleWSKI, Z., GaWOR, J. (2016): Gastrointestinal parasites of the Polish primitive horses from the Biebrza National Park. Helminthologia, 53(1): 39 - 46. DOI:10.1515/ helmin-2015-0065

TRACH, V.N. (1986): Ecological and faunistic characteristics of adult Strongylata of domestic ruminants in Ukraine. Naukova Dumka, Kyiv (In Russian)

ZHARKIKH, T.L. (2003): Body Condition Scoring System for Free Ranging Przewalski horses Equus przewalskii. Gazella, 30: $73-78$

ZIMMERMANN, W. (2004): Naturchutzproject Hortobagy: Jahresbericht 2003 [Nature protection project Hortobagy: Annual report 2003]. Zeitschrift des Kolner Zoo, 47 (1):35 - 48

ZVEGINTSOVA, N.S., ZHARKIKH, T.L., YASYNETSKA, N.I. (2008): Dynamics of Infection with Strongylidae of the Przewalski Horse (Equus przewalskii) Population in the Chernobyl Exclusion Zone. Vestn Zool, $42(4$ - 5): e73 - e78. DOI: 10.2478/v10058-008-0011-5 